\title{
BASIC RADIO PROPAGATION PREDICTIONS FOR AUGUST 1945
}

\section{THREE MONTHS IN ADVANCE}

\author{
ISSUED
}

MAY 1945

PREPARED BY INTERSERVICE RADIO PROPAGATION LABORATORY National Bureau of Standards Washington 25, D. C. 
"This document contains information affecting the national defense of the United States within the meaning of the Espionage Act, 50 U. S. C. 31 and 32. Its transmission or the revelation of its contents in any manner to an unauthorized person is prohibited by law.", 


\section{BASIC RADIO PROPAGATION PREDICTIONS FOR AUGUST 1945 THREE MONTHS IN ADVANCE}

The monthly reports of the IRPL-D series are now distributed to the Army as the TB 11-499 series, by the Adjutant General; to the Navy as the $\mathrm{DNC}-13-1$ series, by the Registered Publications Section, Nivision of Naval Communications; and to others by the IRPL.
This IRPI-D series is a monthly supplement to the IRPL Rachio Propagation Handbook, Part 1, issued by the Army as TM 11-499 and by the Navy as DNC-13-1, and is required in order to make practical application of the basic Handbook.

\section{CONTENTS}

I. Terminology

II. World-wide prediction charts and

their uses map showing zones covered by prediction charts, and auroral zones

F2-zero-muf, in Me, $\mathrm{H}^{r}$ zone, pre-

dieted for August 1945....... Fig. 5

F2-4000-muf, in Me, IT zone,

predicted for August 1945 _._. Fig. 6

F2-zero-muf, in Me, $I$ zone, pre-

dicted for August 1945 .... Fig. 7

F2-4000-muf, in Mc, $I$ zone, pre-

dicted for August 1945_._. _ Fig. 8

F2-zero-muf, in Me, E zone, pre-

dicted for August 1945__. _. Fig. 9

F2-4000-muf, in Mc, E zone, pre-

dicted for August 1945_... Fig. 10

E layer 2000-muf, in Mc, predicted for August 1945_.

Median fEs, in Me, predicted for August 1945

Pereentage of time occurrence for Es in excess of $15 \mathrm{Mr}$, predicted for August 1945

III. Determination of great-circle distances, bearings, location of transmission control points, solar zenith angles.

Great-circle chart, centered on equator, with small circles indicating distances in kilometers

Diagram of transmission path auxiliary to explanation of use of distance-bearing nomogram, figure 4
Page 2

Page 2 Fig. 1

Fig. 11

Fig. 12

Fig. 15

Page 2

Fig. 2

Fig. 3
III. Determination, cte-Continued.

Nomogram for obtaining greatcircle distances, bearings, latitude and longitude of transmission control points, solar zenith angles. Conversion scale for various distance units. Fig. 4

IV. Calculation of maximum usable frequencies and optimum working frequencies ............. Page 3

Nomograms for transforming $F_{2}$ zero-muf and F2-4000-muf to equivalent maximum usable frequencies at intermerliate transmission distances; conversion scale for obtaining optimum working frequencies

Nomogram for transforming $E$ layer 2000-muf to equivalent maximum usable frequencies and optimum working frequencies due to combined offect of $E$ layer and $F 1$ layer at other transmission distances

V. Absorption, ristance range, and lowest useful high frequency _... Page 4 Absorption index chart (exeluding atroral absorption) for August

VI. Sample muf and owf calculations___ Page 5 For short paths (under $4000 \mathrm{~km}$ ) page 5, table 1, page 6, and Fig. 17 For long paths (over $4000 \mathrm{~km}$ ) page 5, table 2, page 7 , and Fig. 18 


\section{TERMINOLOGY}

The following symbols are used, as recommended by the International Radio Propagation Conference held in Tashington, D. C., 17 April to 5 May 1944.

$$
\begin{gathered}
f^{\circ} F 2=\text { ordinary-wave critical frequency } \\
\text { for the } F 2 \text { layer. The term } \\
\text { night } F \text { layer will no longer be } \\
\text { used. The term } F 2 \text { layer is } \\
\text { now used for the night } F \text { as } \\
\text { well as the daytime } F 2 \text { layer. } \\
f^{x} F 2=\text { extraordinary-wave critical fre- } \\
\text { quency for the } F 2 \text { layer. } \\
E s=\text { sporadic, or abnormal } E \text {. }
\end{gathered}
$$

$f E s=\underset{\text { highest frequency of } E s \text { reflec- }}{\text { tions. }}$ tions.

$\begin{aligned} \text { muf or MUF } & =\text { maximum usable frequency. } \\ \text { owf or OWF } & =\text { optimum working frequency. }\end{aligned}$ 4000 -muf chart $=$ contour chart of muf for 4000 kilometer paths.

2000-muf chart $=$ contour chart of muf for 2000kilometer paths.

Zero-muf chart= contour chart of vertical-incidence critical frequency, extraordinary wave.

$K=$ absorption index (ratio of actual absorption to absorption at the subsolar point).

Note.-The designation $F F_{2}$ has been replaced by $F_{2}$.

\section{WORLD.WIDE PREDICTION CHARTS AND THEIR USES}

The charts, figures 5 to 11 , present world-wide predictions of monthly average maximum usable frequencies for August 1945. Conditions may be markedly different on disturbed days, especially in or near the auroral zones, shown on the map of figure 1. The method of prediction is discussed in the IRPL Radio Propagation Handbook, Part 1, War Dept. TM 11-499, Navy Dept. DNC-13-1, p. 52, 53.

Although ionosphere characteristies are roughly similar for locations of equal latitude, there is also a considerable variation with longitude, especially in the case of the $F_{2}$ layer. This "longitude effect" seems to be related to geomagnetic latitude. Attention was first called to this eflect in the report "Radio Propagation Conditions" issued 10 Sept. 1943; it was brought into general operational use in the next issue (14 Oct. 1943).

The longitude effect in the $F 2$ layer is taken care of by providing world charts for three zones, in each of which the ionosphere characteristies are independent of longitude, for practical purposes. These zones are indicated on the world map, figure 1 .

Two F2 charts are provided for each zone, one of which, the "zero-muf chart," shows the vertical- incidence muf, or the critical frequency for the extraordinary wave, and the other, the "4000muf chart," shows the muf for a transmission distance of $4000 \mathrm{~km}$. Do not confuse the zeromuf charts with the $f^{\circ} \mathrm{F} 2$ charts appearing in the previous IRPL reports "Radio Propagation Conditions." (Values of $F 2$ zero-muf exceed those of $f^{\circ} \mathrm{F} 2$ for the same location and local time by an amount approximately equal to half the gyrofrequency for the location. See IRPL Radio Propagation Handbook, Part 1 (War Dept. TM 11-499 and Navy Dept. DNC-13-1), p. 18, 19, 28 , and fig. 9).

The longitude variation is operationally negligible in the case of the normal $E$ layer and therefore only one E-layer chart is provided.

The variation of $f E s$ with geomagnetic latitude seems to be well marked and important. Consequently, in this issue and in future issues, the $f E s$ charts are constructed on the basis of geomagnetic latitude. Since there are, as yet, insufficient correlated data, the $f E s$ charts are still much less precise than the other charts. However, the new $f E \&$ charts are a closer approximation to actual conditions than those previously issued. Instructions for use of the new charts appear in section IV, 3 .

\section{DETERMINATION OF GREAT.CIRCLE DISTANCES, BEARINGS, LOCATION OF TRANSMISSION CONTROL POINTS, SOLAR ZENITH ANGLES}

1. The first step in any radio propagation calculation is the determination of the transmission path, which is the gleat-circle distance between transmitting and receiving stations. Use the world map, figure 1, and the great-circle chart, figure 2, for this purpose, as follows:

a. Place a piece of transparent paper over the map, figure 1, and draw upon it a convenient reference latitude line, the locations of the transmitting and receiving stations, and the meridian whose local times are to be used as the times for calculation.

b. Place this transparency over the chart, figure 2 , and, keeping the reference line at the proper latitude, slide the transparency horizontally until the terminal points marked on it either fall on the same great-circle curve, or fall the same proportional distance between adjacent great-circle curves. Draw in the path.

c. Locate the midpoint of the path, for paths 
under $4000 \mathrm{~km}$, or the "eontrol points," $2000 \mathrm{~km}$ from either end of the path, for paths greater than $4000 \mathrm{~km}$, and use for this purpose the small cireles of figure 2 .

d. Place the transpareney over the predieted ehart at the proper latitude and local time, and read the values of muf ofl the chart, as dirceted in section IV.

2. Great-eirele distances, bearings, loeation of midpoints, or other "eontrol points" $2000 \mathrm{~km}$ in from the ends of the transmission path, as well as solar zenith angles, may be readily obtained from the nomogram, figure 4.

Referring to the auxiliary diagram, figure 3 , let $Z$ and $S$ be the loeations of transmitting and receiving stations, where $Z$ is the west, and $S$ the east end of the path. Consider north latitudes+ and south latitudes-, and take the absolute value of any sums or differenees of angles (without regard to sign). Use the nomogram, figure 4, as follows:

a. To obtain the great-circle distance ZS:

(1) Draw slant line from (lat. of $Z$-lat. of $S$ ) measured up from bottom of left seale, to (lat. of $Z+$ lat. of $S$ ), measured down from top of right sealc.

(2) From the longitude difference between $S$ and $Z$, on bottom scale, measured from left to right, draw vertical line to the slant line obtained in (1). (Use either the longitude difference or $360^{\circ}$ - the longitude difference, whichever is the smaller.)

(3) From the intersection, draw a horizontal line to the left seale. This gives $Z S S$ in degrees.

(4) Convert the distanee $Z S$ to kilometers, statute miles, or nautical miles, hy using the scale at the bottom of figure 4.

b. To obtain the bearing angle PZS:

(1) Subtraet the distance ZS (in degrees) from $90^{\circ}$ to get $h$.

(2) Draw slant line from (lat. $Z-h$ ), measured up from bottom on left scale, to (lat. $Z+h$ ), measured down from top on right seale.

(3) From $\left(90^{\circ}\right.$-lat. $\left.S\right)$ on left, measured up from bottom on left seale, draw horizontal line until it intersects previous slant line.

(4) From the intersection, draw a vertical line to the bottom scale, which gives the bearing angle $P Z S$, in degrees. c. To obtain the bearing angle PSZ:

(1) Repeat steps (1), (2), (3) and (4) in b, interchanging $Z$ and $S$ in all computations. The result obtained is the interior angle $P S Z$, in degrees.

(2) The bcaring angle PSZ is $360^{\circ}$ minus the result obtained in (1) (since bearings are customarily given clockwise from due north).

d. To obtain latitude of $Q$ (mid, or other, point of path):

(1) Obtain $Z Q$ in degrees. If $Q$ is the midpoint of the path, $Z Q$ will be equal to one-half $Z S$. If $Q$ is one of the $2000-\mathrm{km}$ "control points," $Z Q$ will be approximately $18^{\circ}$, or $Z S-18^{\circ}$.

(2) Subtract $Z Q$ from $90^{\circ}$ to get $h^{\prime}$.

(3) Draw slant line from (lat. $Z-h^{\prime}$ ), measured up from bottom of left seale, to (lat. $Z+h^{\prime}$ ), measured down from top on right seale.

(4) From bearing angle PZS, measured to right on bottom scale, draw vertical line to the above slant lime.

(5) From this intersectior, draw horizontal line to left seale.

(6) Subtract the reading given from $90^{\circ}$ to give latitude of $Q$ in degrees.

e. To obtain longitude difference, $t^{\prime}$, between $Z$ and Q:

(1) Draw straight line (lat. Z-lat. Q), measured up from bottom on left-hand scale, to (lat. $Z$ +lat. Q), measured down from top on righthand scale.

(2) From the left side, at $Z Q$, in degrees, draw a horizontal line to the above slant line.

(3) From the interseetion, drop a vertical line to bottom scale to get $t^{\prime}$ in degrees.

f. To obtain solar zenith angle, $\psi$, at a given place:

(1) Let the declination of the sum be $d$, and let $Z$ be the plaee under consideration.

(2) Draw straight line from (lat. $Z-d$ ), measured up from bottom on left seale, to (lat. $Z+d$ ), measured down on right scale.

(3) From [(12-local time of $Z$, in hours $) \times 15]$ degrees, on bottom scale, measured from left to right, draw a vertical line to the slant line above.

(4) From this interscetion, draw a horizontal line to the left seale. This gives $\psi$, in degrees.

\section{CALCULATION OF MAXIMUM USABLE FREQUENCIES AND OPTIMUM WORKING FREQUENCIES \\ 1. PROCEDURE FOR DETERMINATION OF MUF OR OWF FOR TRANSMISSION DISTANCES UNDER $4000 \mathrm{KM}$}

Radio propagation over distanees up to 4000 $\mathrm{km}$ is usually determined by ionospheric eonditions at the midpoint of the great-eirele path between transmitting and receiving station.

For a path $4000 \mathrm{~km}$ in length, read the predieted monthly average $F 2$ muf directly off the 4000-muf charts furnished, at the latitude and loeal time of the midpoint of the path. For a path $2000 \mathrm{~km}$ in length rearl the predieted monthly average $E$-layer muf directly off the E-layer 2000-muf ehart. Use the following procedure for other distances:

a. Locate the midpoint of the transmission path. (Methods for doing this are given in the preceding seetion of this report.) 
b. Read the values of F2-zero-muf, F2-4000muf, and E-layer 2000-muf for the midpoint of the path at the local time for this midpoint. Be sure to choose the F2 charts for the geographical zone in which the midpoint lies.

c. Place a straightedge between the values of F'z-zero-muf and F2-4000-muf at the left-and right-hand sides, respectively, of the grid nomogram, figme 13, and read the value of the muf for the actual path length at the intersection point of the straightedge with the appropriate vertical distance line.

d. The optimum working frequency (owf) is 85 pereent of the muf, to allow a margin of safety for day-to-day variations; to determine the owf, use the auxiliary scale at the right of the grid nomogram of figure 13.

e. Place a straightedge between the value of the E-layer 2000-muf located on the loft-hand scale of the nomogram, figure 14, and the value of the path length on the right-hand scale, and read the combined E- and F1-layer muf or owf for that path length, off the central scale. (The characteristics of the $E$ layer and of the F1 layer are sufficiently related that, for most practical purposes, they may be combined in this mamner.)

f. Compare the values of muf or owf obtained by operations c to e. The higher of the two values thus determined is the muf or owf for the path.

\section{PROCEDURE FOR DETERMINATION OF MUF OR OWF FOR TRANSMISSION DISTANCES GREATER THAN 4000 KM}

The complexities of long-clistance rarlio propagation are such that the simple multiliop $E$ or $F 2$ layer calculations do not give accurate results. The following procedure will give results which are operationally satisfactory; the theory involved is outside the scope of this report.

a. Locate the two "control points" $2000 \mathrm{~km}$ from the ends of the great-circle distance between transmitting and receiving stations. For very long paths both the "short route" (minor" are of the great-circle path) and the "long route" (major are) need to be considered.

b. Read the value of the F2-4000-muf, at the local time for each point, at these points, being sure to choose the appropriate zone for each point.

c. Compane these two muf values. The lower of the two is the muf for the transmission path under consileration. Calculate the owf $(85 \%$ of the muf) for the path, by means of the auxiliary muf-owf scale of figure 13 .

d. When one of the control points lies in a region where the E-2000-muf is greater thas the F2-4000-muf, read the E-2000-muf at an E-layer control point $1000 \mathrm{~km}$ from the end of the path, instead of the $F 2-4000$-muf, as in step b. Use the E-2000-mul' in step c, instead of the F2-4000-muf.

\section{PROCEDURE FOR DETERMINATION OF ES TRANSMISSION}

\section{(Note Change in Charts and Procedure)}

Sporalice-E (Es) propagation plays an important part in transmission over paths in some parts of the world and at certain times. It may often allow regular transmission at times when regular F2-layer propagation would not. Es data are not yet sufficient to permit aeculate calculations of such propagation, hut the $f E s$ charts of figures 12 and 15 are given as a guide to Es oceurrence. These charts are of a now type this month.

Since the fEs clarts are construeted from considerations of geomagnetic latitude, three latitude scales are provided at the right of the charts of figures 12 and 15, one for each of the three zones of figure $1(H, l$, and $E)$.

Until further improvements are made the following procedure should be used to find the prevalence of Es propagation over a transmission paíh. a. For paths over $4000 \mathrm{lim}$ long:

(1) Place the great-circle path transparency prepared in section III, 1, over the median fEs chart, figure 12, using the latitude scale for the zone containing the control point.

(2) Scale fEs at each E-laycl control point (1000 km from either end of the path), multiply by 5 and subtract $4 \mathrm{Mc}$. The result is the Es-owf.

(3) Plot as the owf for each control point the highest of the three values; the F2-4000-owf, the E-2000-owf, and the Es-owf.

b. For paths less than $4000 \mathrm{~km}$ long, scale the fEs at the midpoint of the path, using the latitude seale for the appropriate zone, multiply by 5 and subtract 4 Me, and use the resultant frequency as outlined above for the E-layer 2000muf in the nomogram of figure 14. The result is the les-owf. 


\section{ABSORPTION, DISTANCE RANGE, AND LOWEST USEFUL HIGH FREQUENCY}

The determination of absorption, distance range, and lowest useful high frequency is discussed at length in IRPL Radio Propagation IIandbook, Part 1, p. 69-97 (War Dept. TM 11-499, Navy Dept. DNC-13-1), and formulas, graphs, and nomograms for calculation are given there. For convenience in estimating absorption (exchusive of attroral absorption) over a path, the absorption index (or $K$ ) chart, figure 16 , is presented. By superposing on this chart the transparency with the great-circle path, prepared as in section III, 1, the relation of the path to the sun's zenith angle is readily seen (the sumise-sunset line corresponds to an absorption index approximately $=0.14$ ).

The absorption is crratic and considerably greater in and noar the auroral zones, shown on the map of figure 1 ; paths passing though or near these zones are subject at times to severe disturbances.

\section{SAMPLE MUF AND OWF CALCULATIONS}

\section{FOR SHORT PATHS}

Required: The muf and owf for transmission between Washington, D. C. $\left(39.0^{\circ} \mathrm{N}, 77.5^{\circ} \mathrm{W}\right)$ and Miami, Fla. $\left(25.7^{\circ} \mathrm{N}, 80.5^{\circ} \mathrm{W}\right)$ for arerage conditions during the month of August 1945.

\section{Solution:}

Let the local time used for this problem be GCT ( $Z$ time or that of $0^{\circ}$ longitude).

The midpoint of the path is at approximately $32.5^{\circ} \mathrm{N}, 79.0^{\circ} \mathrm{W}$, and the transmission path length is approximately $1500 \mathrm{~km}$.

The values of $E$-and $F 2$-layer muf and owf, and also Es-owf for alternate hours, GCT, as determined loy using the procedure given in section $\mathrm{IV}^{\top}$, are given in table 1. The final values are presented graphically iu figure 17 . In obtaining the combined muf for all layers, the Es-owf is used because of the great variability of the muf.

Figure 17 shows that skip will oceur, on the average, during the night hours, if a frequeney as high as $10.0 \mathrm{Mc}$ is used. A frequeney as high as
8.0 Me will not skip, on the avelage, at any time of day, but its use is not advisable berause of (a) the day-to-day variability, causing some probability of skip during the night loums, and (b) ionospheric absorption during the daytime, which is more pronounced at low frepuencirs

$\Lambda$ satisfactory frequency plan to insure contiunous transmission at all times, over a path like this, involves the use of two frequencies, one for night, and one for day. Figure 17 shows that a night frecpency of 8.2 Me, to be used from 2130 to 1310 GC'T, and a day frequency of 12.1 Me, to be used between 1310 and 2130 (iCT, woukd be satisfactory. The periods of usefuhness of these frequencies are shown by the heary dashed line on figure 17

Periods of time during which transmission is controlled by rither the $E$ layer or the F2 layer may be easily reognized by noting the relative proximity of the muf and owf curves of figure 17. Coincidence of the curves indieates comtrol by sporaclic-E a eflections.

\section{FOR LONG PATHS}

Required: The muf and owf for transmission between Shanghai, China $\left(31.2^{\circ} \mathrm{N}, 122.2^{\circ} \mathrm{E}\right)$ and San Francisco, Calif. $\left(37.8^{\circ} \mathrm{N}, 122.4^{\circ} \mathrm{W}\right)$, for average conditions during the month of August 1945 .

\section{Solution:}

Let the local time for this problem be GCT ( $Z$ time or that of $0^{\circ}$ longitude).

The path length is approximately $10,000 \mathrm{~km}$, and the two F2-layer control points, $A$ and $B$ respectively, are at approximately $43^{\circ} \mathrm{N}, 139^{\circ} \mathrm{E}$ and $48^{\circ} \mathrm{N}, 143^{\circ} \mathrm{W}$. These are, respectively, in the $E$ zone and the $I$ zone, as shown on the map, figure 1. The two E-layer and Es-control points, $A^{\prime}$ and $B^{\prime}$, respectively, are located at $37.5^{\circ} \mathrm{N}$, $127^{\circ} \mathrm{E}$, and $43^{\circ} \mathrm{N}, 133^{\circ} \mathrm{E}$. The bearing of San Francisco from Shanghai is approximately $45^{\circ}$, and of Shanghai from San Francisco is approximately $310^{\circ}$, both determined by means of the nomogram of figure 4.

The values of muf and owf over this transmission path, as determined by using the procedure of section $I V$, are giron in talle 2 for alternate hours, GC'T. The fimal values are shown graphically in figure 18 .

Figure 18 shows that skip will occur, on the average, during the night hours if a frequeney as high as $10 \mathrm{Me}$ is used, although higher frequeneies may be used during a limited portion of the day.

$A$ good practical arrangement to insure continuous transmission at all times is to select three frequencies, in a manner similar to that suggested in the preceding problem. A frequency of 6.5 Me may be used from 0840 to 1845 GC'T; a lrequency of 13.7 Me may be used from 2110 to 0620 GCT; and a transition frequeney of 8.7 Me may be used from 0620 to $0840 \mathrm{GCT}$, and from 1845 to $2110 \mathrm{GCT}$.

Relative proximity of the muf and owf curves of figure 18 indicates that neither Es nor regular E-layer controls transmission at any lime.

By inspection of the absorption chart, figure 16, and the noise map (fig. 119 of the IRPL Radio Propagation Handbook, Part 1, War Dept. TM 11-499, Navy Dept. DNC-13-1), it may be 
seen that considerations of the lowest useful high frequency over this path may be of considerable importance in selecting frequencies for use. Consequently, in cases of transmission failure on the frequencies here recommended, particularly in the case of the transition frequency, changing the frequency to a value slightly under the muf for the path may be advisable.

\section{TABLE 1.- Solution of short-path transmission problem}

[Washington, D. C., to Miami, Fla., August 1945]

\begin{tabular}{|c|c|c|c|c|c|c|c|c|c|c|c|c|}
\hline Time, GCT & $\begin{array}{c}\text { E-layer- } \\
2000- \\
\text { muf }\end{array}$ & $\begin{array}{c}\text { Com- } \\
\text { bined } \\
E \text { and } \\
F 1 \text {-layer } \\
1500- \\
\text { muf }\end{array}$ & $\begin{array}{l}\text { Com- } \\
\text { bined } \\
E \text { and } \\
F 1-\text { layer } \\
1500^{-} \\
\text {owf }\end{array}$ & $\begin{array}{l}\text { Median } \\
\text { fFs }\end{array}$ & $\begin{array}{c}E s-2000- \\
\text { owf }\end{array}$ & $\begin{array}{c}E s-1500- \\
\text { owf }\end{array}$ & $\begin{array}{c}F 2- \\
\text { layer- } \\
\text { zero- } \\
\text { muf, } \\
W \\
\text { zone }\end{array}$ & $\begin{array}{c}F 2- \\
\text { layer- } \\
4000- \\
\text { muf, } \\
W \\
\text { zone }\end{array}$ & $\begin{array}{c}F 2- \\
\text { layer- } \\
1500- \\
\text { muf }\end{array}$ & $\begin{array}{c}F 2- \\
\text { layer- } \\
1500- \\
\text { owf }\end{array}$ & $\begin{array}{c}\text { Com- } \\
\text { bined } \\
\text { muf, } \\
\text { all } \\
\text { layers }\end{array}$ & $\begin{array}{c}\text { Com- } \\
\text { bined } \\
\text { owf, } \\
\text { all } \\
\text { layers }\end{array}$ \\
\hline $\begin{array}{l}00 \ldots \ldots \\
02 \ldots \ldots \\
04 \ldots \ldots \\
06 \ldots \ldots \ldots \ldots\end{array}$ & $\begin{array}{l}M c \\
6.2 \\
\ldots\end{array}$ & $\begin{array}{l}M c \\
5.7 \\
\ldots \\
\ldots\end{array}$ & $\begin{array}{l}M c \\
5.5 \\
-\ldots \\
-\ldots\end{array}$ & $\begin{array}{l}M c \\
2.7 \\
2.9 \\
3.1 \\
3.1\end{array}$ & $\begin{array}{l}M c \\
9.5 \\
10.5 \\
11.5 \\
11.5\end{array}$ & $\begin{array}{r}\text { Mc } \\
8.7 \\
9.6 \\
10.3 \\
10.3\end{array}$ & $\begin{array}{l}M C \\
6.5 \\
5.7 \\
4.6 \\
4.0\end{array}$ & $\begin{array}{l}\wedge c \\
20.6 \\
17.1 \\
12.2 \\
10.8\end{array}$ & $\begin{array}{r}M c \\
12.1 \\
10.2 \\
7.7 \\
6.8\end{array}$ & $\begin{array}{r}\text { Hc } \\
10.2 \\
8.6 \\
6.6 \\
5.8\end{array}$ & $\begin{array}{l}\text { Mc } \\
12.1 \\
10.2 \\
10.3 \\
10.3\end{array}$ & $\begin{array}{r}\text { Mc } \\
10.2 \\
9.6 \\
10.3 \\
10.3\end{array}$ \\
\hline $\begin{array}{l}08 \ldots \\
10 \\
12 \ldots \\
14 \ldots \ldots\end{array}$ & 11.1 & 10.2 & 10. 0 & $\begin{array}{l}2.9 \\
2.9 \\
\text { 3. } 0 \\
\text { 3. } 0\end{array}$ & $\begin{array}{l}\text { 10.5 } \\
10.5 \\
11.0 \\
11.0\end{array}$ & $\begin{array}{r}9.6 \\
9.6 \\
10.0 \\
10.0\end{array}$ & $\begin{array}{l}3.5 \\
\text { 3. } 4 \\
\text { 5. } 2 \\
\text { 5. } 8\end{array}$ & $\begin{array}{r}8.9 \\
8.8 \\
15.2 \\
17.2\end{array}$ & $\begin{array}{r}5.7 \\
5.6 \\
9.1 \\
10.3\end{array}$ & $\begin{array}{l}4.8 \\
4.7 \\
7.7 \\
8.7\end{array}$ & $\begin{array}{r}9.6 \\
9.6 \\
10.2 \\
13.9\end{array}$ & $\begin{array}{r}9.6 \\
9.6 \\
10.0 \\
13.4\end{array}$ \\
\hline $\begin{array}{l}16 \ldots \ldots \\
18 \ldots \ldots \ldots \\
20 \ldots \ldots \ldots \\
22 \ldots \ldots \ldots \ldots\end{array}$ & $\begin{array}{l}16.6 \\
16.8 \\
16.0 \\
13.0\end{array}$ & $\begin{array}{l}15.1 \\
15,2 \\
14,7 \\
11.9\end{array}$ & $\begin{array}{l}\text { 14. } 8 \\
15.0 \\
14.2 \\
11.5\end{array}$ & $\begin{array}{ll}3 . & 0 \\
2 . & 8 \\
2 . & 6 \\
2 & 6\end{array}$ & $\begin{array}{r}11.0 \\
10.0 \\
9.0 \\
9.0\end{array}$ & $\begin{array}{r}10.0 \\
9.2 \\
8.2 \\
8.2\end{array}$ & $\begin{array}{l}6.3 \\
6.6 \\
6.7 \\
6.6\end{array}$ & $\begin{array}{l}17.8 \\
19.0 \\
20.0 \\
20.1\end{array}$ & $\begin{array}{l}10.9 \\
11.5 \\
12.0 \\
12.0\end{array}$ & $\begin{array}{r}9.2 \\
9.7 \\
10.2 \\
10.2\end{array}$ & $\begin{array}{l}\text { 15. } 1 \\
15.2 \\
14.7 \\
12.0\end{array}$ & $\begin{array}{l}14.8 \\
15.0 \\
14.2 \\
11.5\end{array}$ \\
\hline
\end{tabular}


TABLE 2.-Solution of long-path transmission problem

[Shanghai, China, to San Francisco, Calif., August 1945]

\begin{tabular}{|c|c|c|c|c|c|c|c|c|c|c|}
\hline Time, GCT & $\begin{array}{l}\text { E-layer- } \\
2000 \text {-muf, } \\
\text { control } \\
\text { point } A^{\prime}\end{array}$ & $\begin{array}{l}\text { E-layer- } \\
2000-0 w f \\
\text { control } \\
\text { point } 1^{\prime}\end{array}$ & $\begin{array}{l}\text { Median } \\
\text { fEs, con- } \\
\text { trol point } \\
A^{\prime}\end{array}$ & $\begin{array}{c}E s \text {-owf, } \\
\text { control } \\
\text { point } A^{\prime}\end{array}$ & $\begin{array}{l}F 2-4000- \\
\text { muf, } E- \\
\text { zone, con- } \\
\text { trol point } \\
\quad A^{\prime}\end{array}$ & $\begin{array}{l}F 2-4000- \\
\text { owf, } E= \\
\text { zone, con- } \\
\text { trol point } \\
\quad A\end{array}$ & $\begin{array}{l}\text { Combined } \\
\text { muf, con- } \\
\text { trol points } \\
A \text { and } A^{\prime}\end{array}$ & $\begin{array}{l}\text { Combined } \\
\text { owf, con- } \\
\text { trol points } \\
A \text { and } A^{\prime}\end{array}$ & $\begin{array}{c}\text { E-layer- } \\
2000 \text {-muf, } \\
\text { control } \\
\text { point } B^{\prime}\end{array}$ & $\begin{array}{l}E \text {-layer } \\
2000-0 \text { wf } \\
\text { control } \\
\text { point } B\end{array}$ \\
\hline $\begin{array}{l}00 \\
02 \\
04 \\
06\end{array}$ & $\begin{array}{l}M c \\
\text { 14. } 6 \\
16.2 \\
16.4 \\
15.8\end{array}$ & $\begin{array}{l}M f C \\
14.1 \\
15.8 \\
16.0 \\
15.2\end{array}$ & $\begin{array}{l}M c \\
\overline{2} . \overline{2} \\
2.2 \\
2.2\end{array}$ & $\begin{array}{l}\text { Mc } \\
7.0 \\
7.0 \\
7.0\end{array}$ & $\begin{array}{l}M c \\
18.4 \\
20.8 \\
20.5 \\
19.8\end{array}$ & $\begin{array}{l}M c \\
15.7 \\
17.7 \\
17.4 \\
16.8\end{array}$ & $\begin{array}{l}M c \\
18.4 \\
20.8 \\
20.5 \\
19.8\end{array}$ & $\begin{array}{l}\text { Mc } \\
15.7 \\
17.7 \\
17.4 \\
16.8\end{array}$ & $\begin{array}{r}M c \\
14.8 \\
11.6 \\
5.7\end{array}$ & $\begin{array}{l}M c . \\
14.2 \\
11.2 \\
5.5\end{array}$ \\
\hline $\begin{array}{l}08 \\
10 \\
12 \\
14\end{array}$ & $\begin{array}{r}13.3 \\
7.7 \\
-\end{array}$ & $\begin{array}{r}12.9 \\
7.5 \\
-\end{array}$ & $\begin{array}{l}2.8 \\
-\cdots \\
-\cdots\end{array}$ & 10.0 & $\begin{array}{l}21.0 \\
19.9 \\
16.8 \\
12.1\end{array}$ & $\begin{array}{l}\text { 17. } 8 \\
16.9 \\
14.2 \\
10.2\end{array}$ & $\begin{array}{l}21.0 \\
19.9 \\
16.8 \\
12.1\end{array}$ & $\begin{array}{l}\text { 17. } 8 \\
16.9 \\
14.2 \\
10.2\end{array}$ & 6. 8 & $-\overline{6}$ \\
\hline $\begin{array}{l}16 \\
18 \\
20 \\
22\end{array}$ & $10 . \overline{6}$ & 10.2 & $\begin{array}{l}-- \\
--- \\
--- \\
---\end{array}$ & 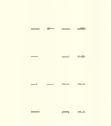 & $\begin{array}{r}9.5 \\
9.4 \\
12.5 \\
17.5\end{array}$ & $\begin{array}{r}8.1 \\
8.0 \\
10.7 \\
14.9\end{array}$ & $\begin{array}{r}9.5 \\
9.4 \\
12.5 \\
17.5\end{array}$ & $\begin{array}{r}\text { 8. } 1 \\
8.0 \\
\text { 10. } 7 \\
14.9\end{array}$ & $\begin{array}{l}\text { 12. } 4 \\
15.0 \\
16.0 \\
15.9\end{array}$ & $\begin{array}{l}\text { 12. } 0 \\
14.6 \\
15.4 \\
15.3\end{array}$ \\
\hline \multicolumn{3}{|l|}{ Time, GCT } & $\begin{array}{l}\text { Median } \\
f E s, \text { con- } \\
\text { trol point } \\
B^{\prime}\end{array}$ & $\begin{array}{c}E s \text {-owf } \\
\text { control } \\
\text { point } B^{\prime}\end{array}$ & $\begin{array}{l}F 2-4000- \\
\text { muf, } I- \\
\text { zone, con- } \\
\text { trol point } \\
\qquad B\end{array}$ & $\begin{array}{l}F 2-4000- \\
\text { owf, } I \\
\text { zone, con- } \\
\text { trol point } \\
\quad B\end{array}$ & $\begin{array}{l}\text { Combined } \\
\text { muf, con- } \\
\text { trol points } \\
B \text { and } B^{\prime}\end{array}$ & $\begin{array}{l}\text { Combined } \\
\text { owf, con- } \\
\text { trol points } \\
B \text { and } B^{\prime}\end{array}$ & $\begin{array}{l}\text { Muf for } \\
\text { trans- } \\
\text { mission } \\
\text { path }\end{array}$ & $\begin{array}{l}\text { Owf for } \\
\text { trans- } \\
\text { mission } \\
\text { path }\end{array}$ \\
\hline $\begin{array}{l}00 \\
02 \\
04 \\
06\end{array}$ & & & $\begin{array}{l}M c \\
2.5 \\
2.5 \\
2.6 \\
2.8\end{array}$ & $\begin{array}{r}M c \\
8.5 \\
8.5 \\
9.0 \\
10.0\end{array}$ & $\begin{array}{c}M c \\
16.3 \\
16.6 \\
19.3 \\
17.5\end{array}$ & $\begin{array}{l}M f c \\
13.9 \\
14.1 \\
16.3 \\
14.9\end{array}$ & $\begin{array}{c}M c \\
16.3 \\
16.6 \\
19.3 \\
17.5\end{array}$ & $\begin{array}{c}M c \\
13.9 \\
14.1 \\
16.3 \\
14.9\end{array}$ & $\begin{array}{c}M c \\
16.3 \\
16.6 \\
19.3 \\
17.5\end{array}$ & $\begin{array}{l}M c \\
13.9 \\
14.1 \\
16.3 \\
14.9\end{array}$ \\
\hline $\begin{array}{l}08 \ldots \\
10 \\
12\end{array}$ & & & $\begin{array}{l}\text { 3. } 1 \\
\text { 3. } 0 \\
2.7 \\
\text { 3. } 0\end{array}$ & $\begin{array}{r}11.5 \\
11.0 \\
9.5 \\
11.0\end{array}$ & $\begin{array}{r}\text { 11. } 6 \\
9.2 \\
7.9 \\
9.0\end{array}$ & $\begin{array}{l}9.8 \\
\text { 7. } 8 \\
6.7 \\
7.7\end{array}$ & $\begin{array}{r}\text { 11. } 6 \\
9.2 \\
7.9 \\
9.0\end{array}$ & $\begin{array}{l}9.8 \\
\text { 7. } 8 \\
\text { 6. } 7 \\
\text { 7. } 7\end{array}$ & $\begin{aligned} \text { 11. } 6 \\
9.2 \\
\text { 7. } 9 \\
9.0\end{aligned}$ & $\begin{array}{l}\text { 9. } 8 \\
\text { 7. } 8 \\
\text { 6. } 7 \\
\text { 7. } 7\end{array}$ \\
\hline $\begin{array}{l}16 \ldots \\
18 \ldots \\
20 \\
22\end{array}$ & & & $\begin{array}{l}\text { 3. } 2 \\
\text { 3. } 1 \\
\text { 3. } 0 \\
2.9\end{array}$ & $\begin{array}{l}12.0 \\
11.5 \\
11.0 \\
10.5\end{array}$ & $\begin{array}{l}14.1 \\
16.2 \\
16.6 \\
16.7\end{array}$ & $\begin{array}{l}\text { 12. } 0 \\
13.8 \\
14.1 \\
14.2\end{array}$ & $\begin{array}{l}\text { 14. } 1 \\
16.2 \\
16.6 \\
16.7\end{array}$ & $\begin{array}{l}\text { 12. } 0 \\
\text { 13. } 8 \\
\text { 15. } 4 \\
15.3\end{array}$ & $\begin{array}{r}9.5 \\
9.4 \\
\text { 12. } 5 \\
16.7\end{array}$ & $\begin{aligned} 8.1 \\
8.0 \\
10.7 \\
14.9\end{aligned}$ \\
\hline
\end{tabular}




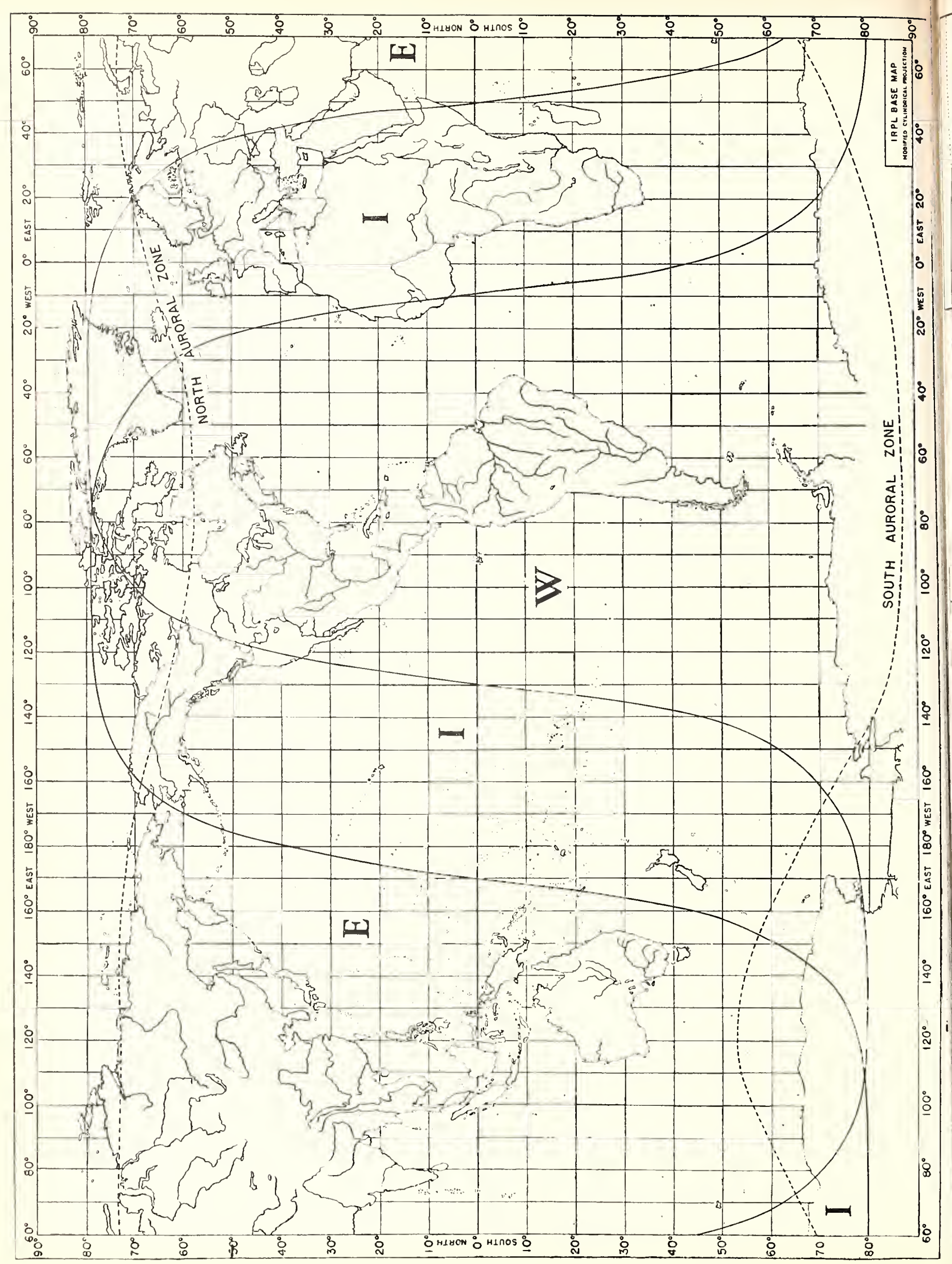



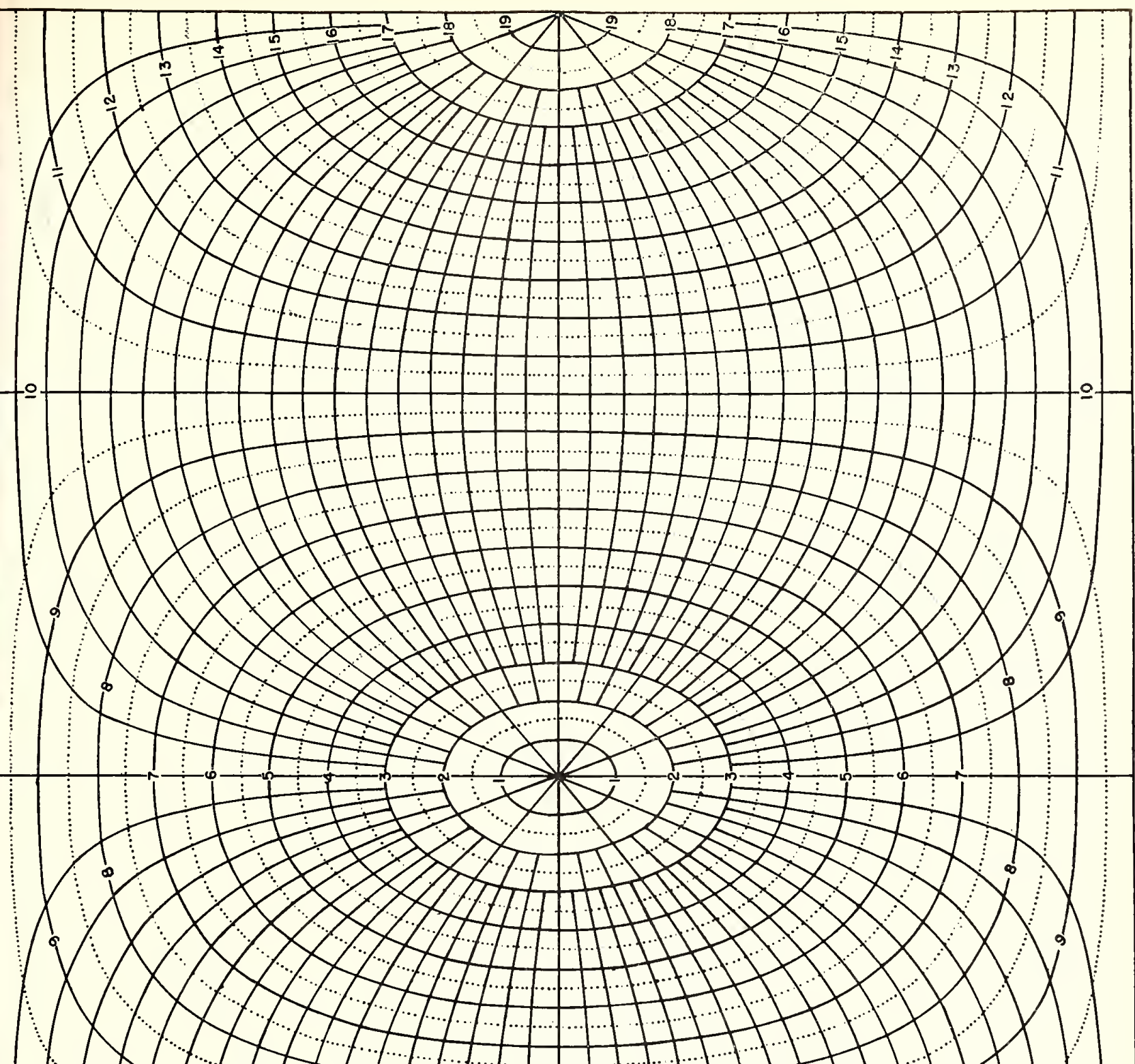

으

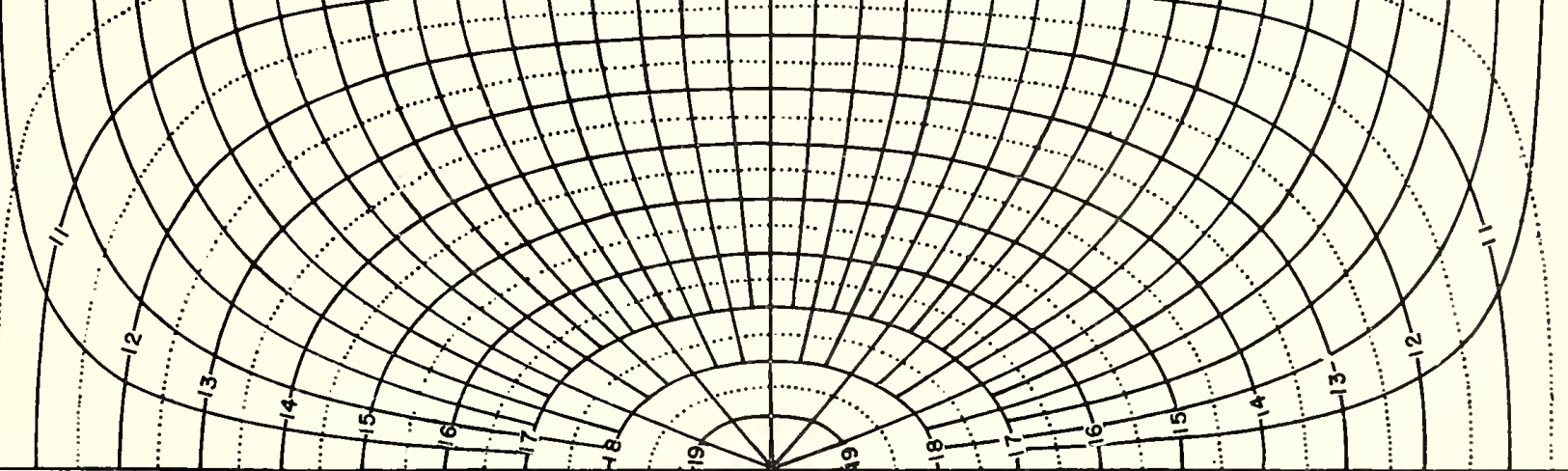

FIG. 2. GREAT CIRCLE CHART, CENTERED ON EQUATOR, WITH SMALL CIRCLES INDICATING DISTANCES IN KILOMETERS. 


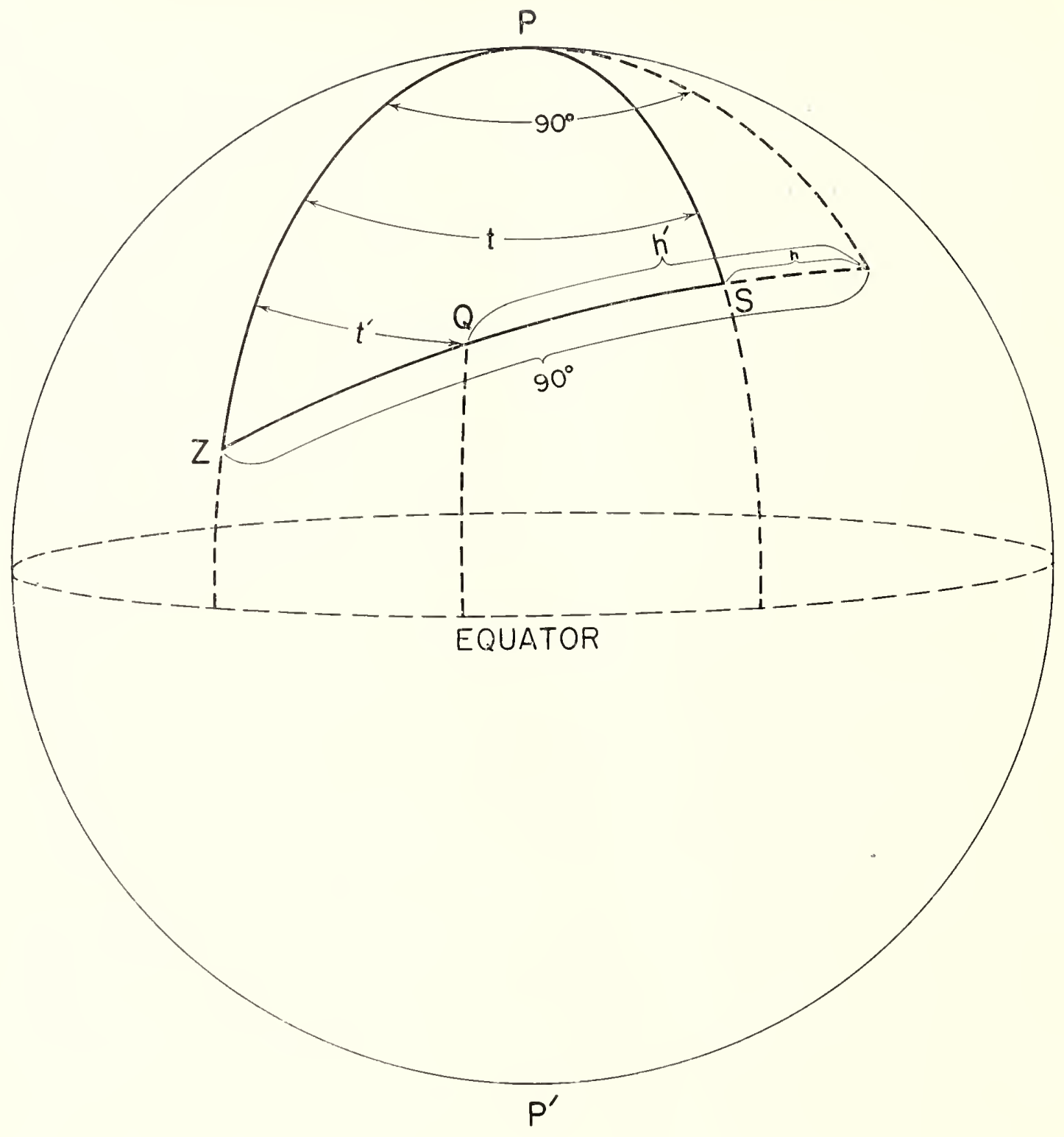

Fig. 3. DIAGRAM OF TRANSMISSION PATH AUXILIARY TO EXPLANATION OF USE OF DISTANCE - BEARING NOMOGRAM, FIG. 4. 


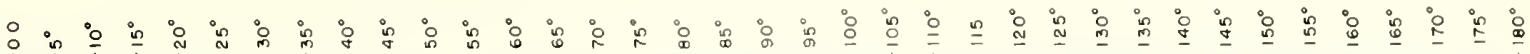
.

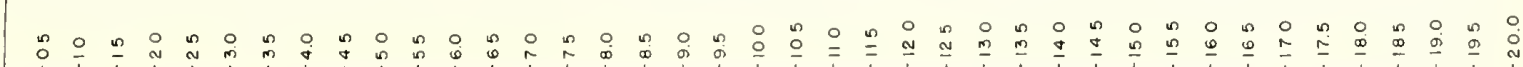

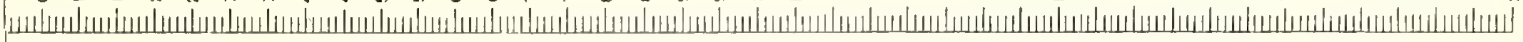

Thousonds ot
Miles

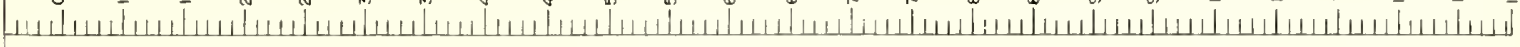

Thousonds of
Nouticol Miles

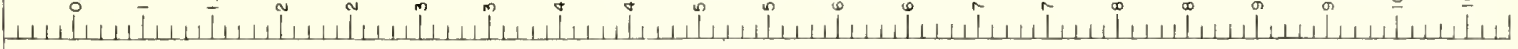

Degrees

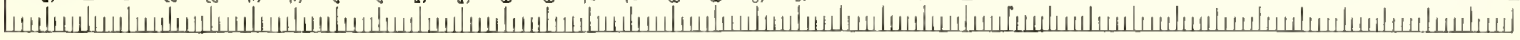

Fig. 4. NOMOGRAM (AFTER D'OCAGNE) FOR OBTAINING GREAT-GIRCLE DISTANCES, BEARINGS, LATITUDE AND LONGITUDE OF TRANSMISSION CONTROL POINTS, SOLAR ZENITH ANGLES. 


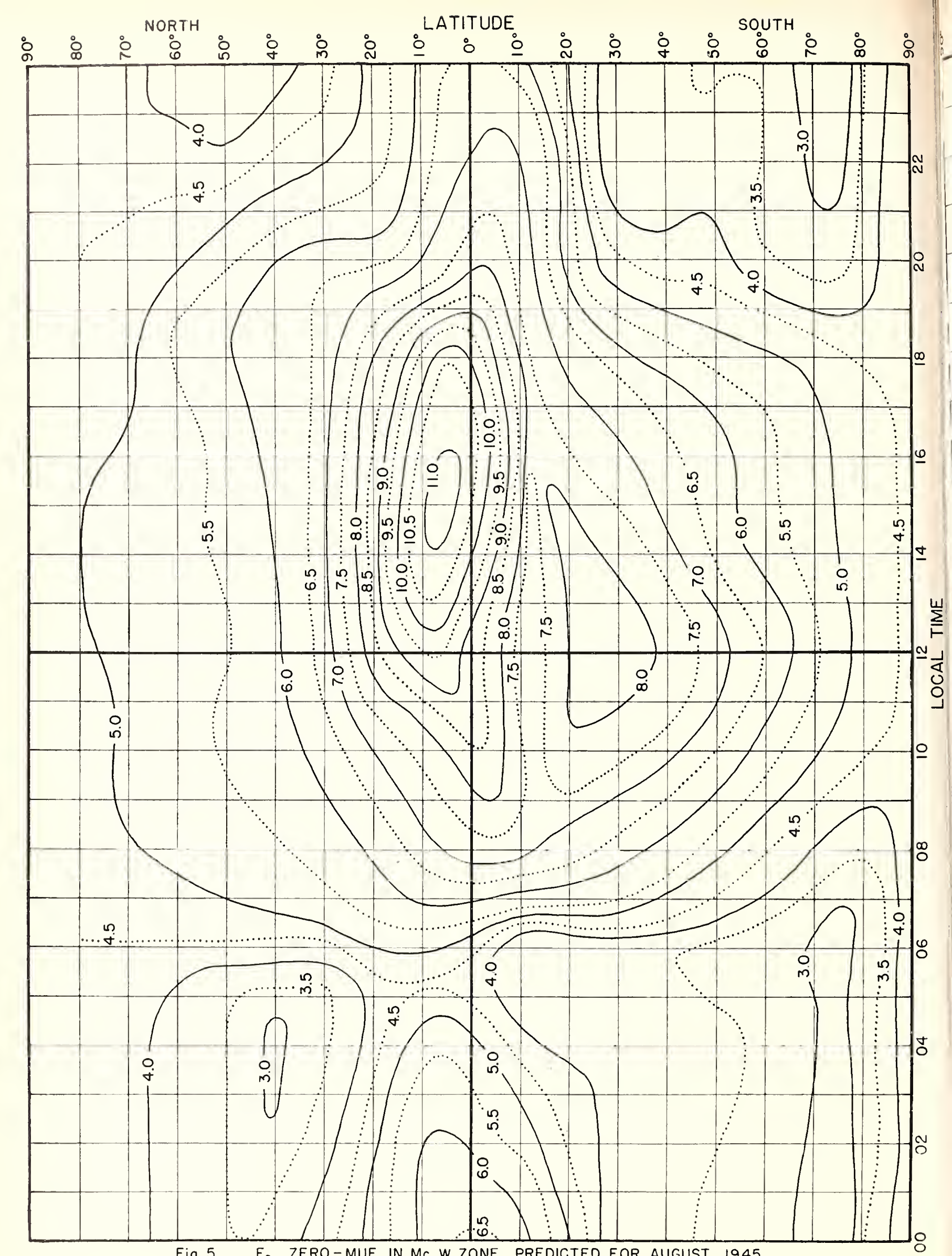






Fig. 6. $F_{2}$ 4000-MUF, IN Mc, W ZONE, PREDICTED FOR AUGUST, 1945. 


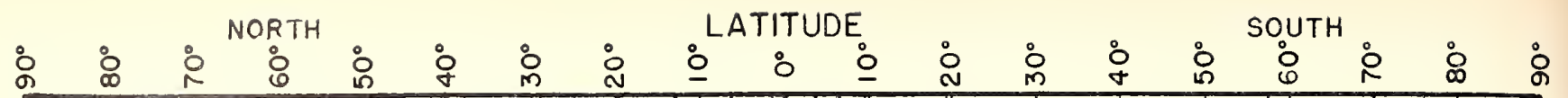

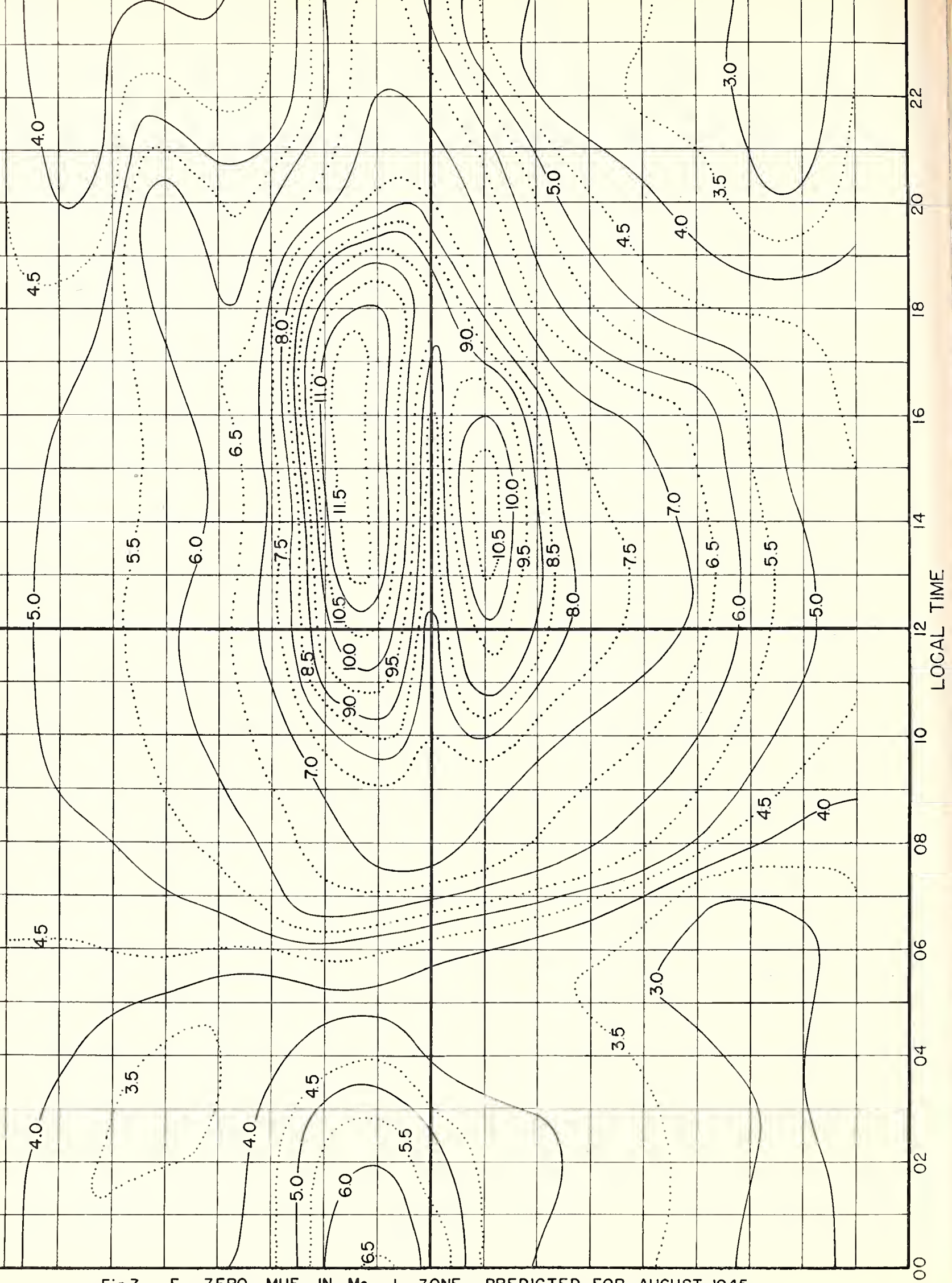

Fig.7. $F_{2}$ ZERO-MUF, IN MC, I ZONE, PREDICTED FOR AUGUST, 1945. 


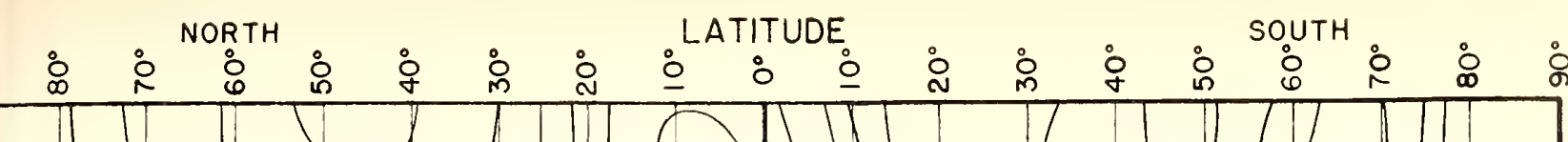
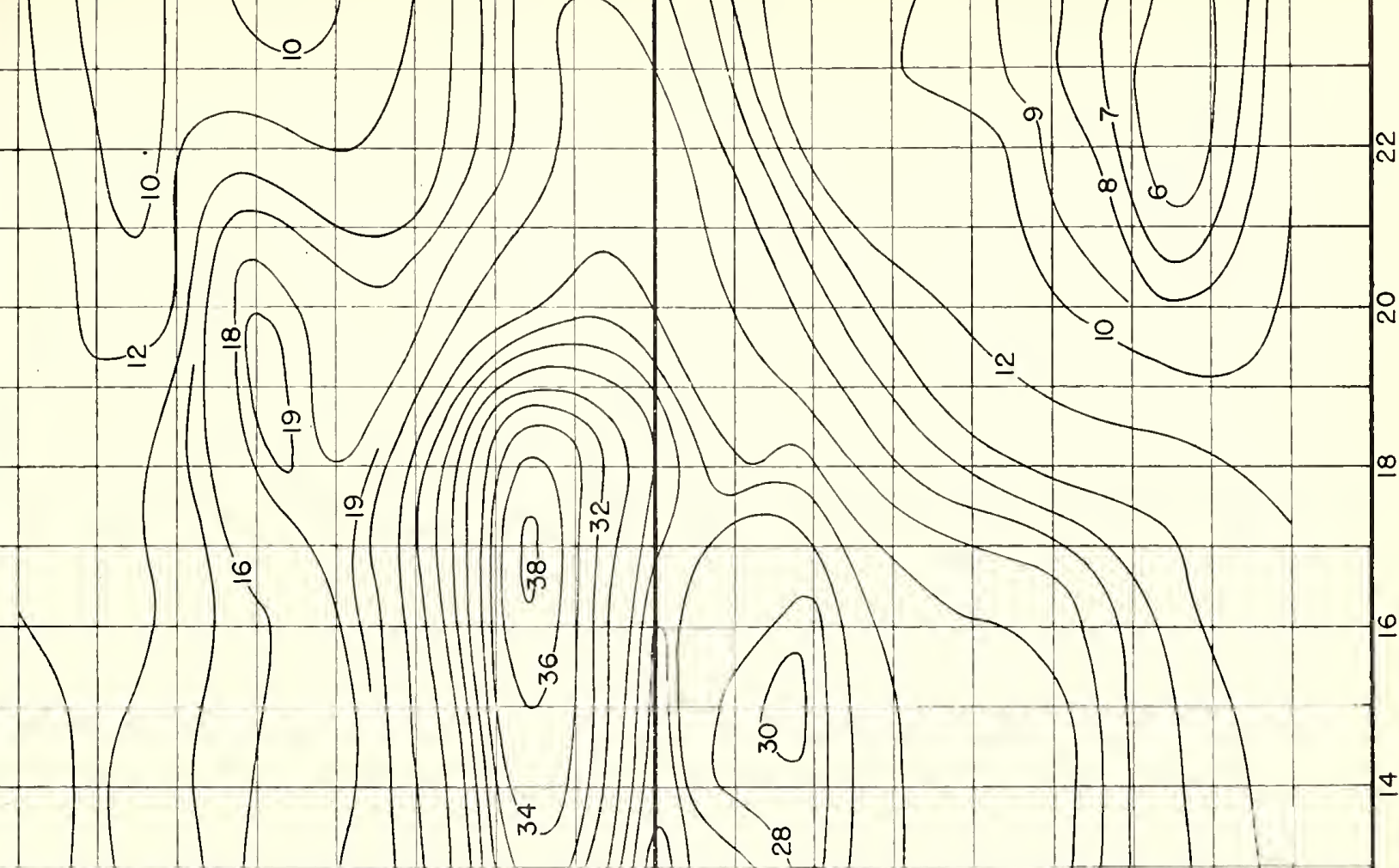

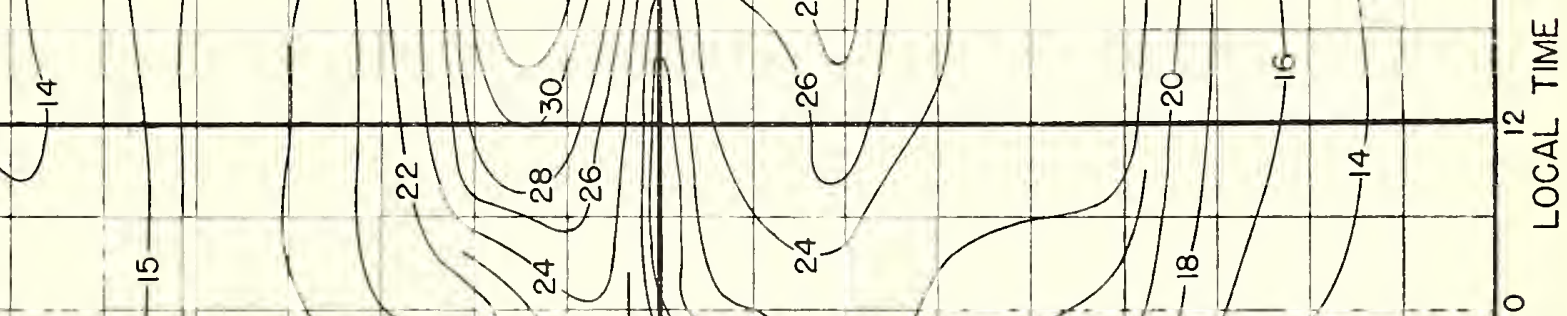
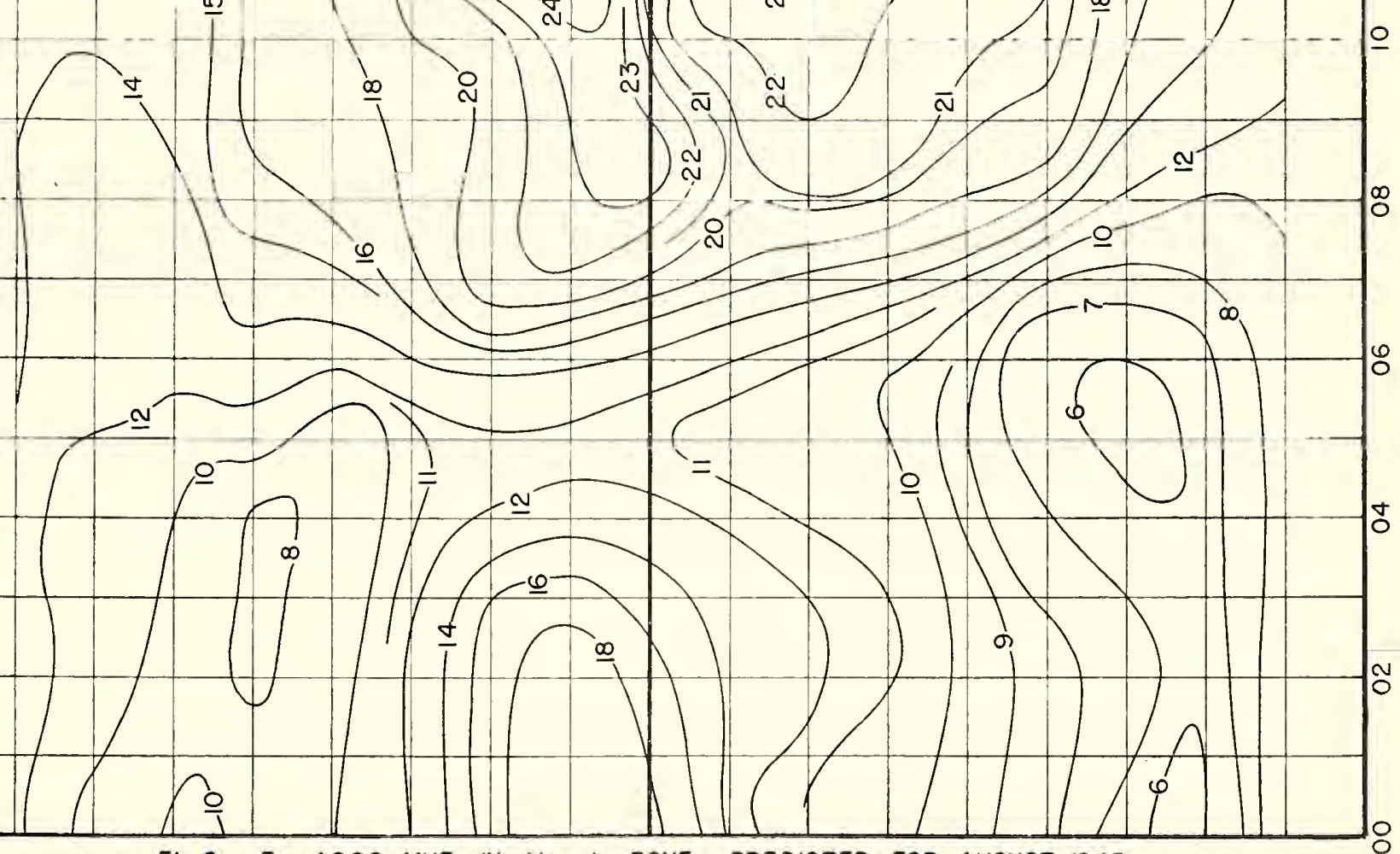

Fig. 8. $F_{2} 4000$ MUF, IN MC, I ZONE, PREDICTED FOR AUGUST, 1945 


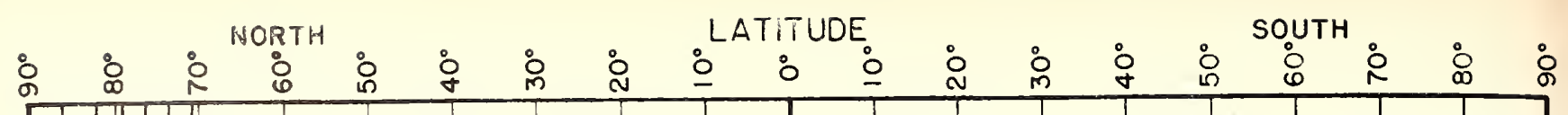
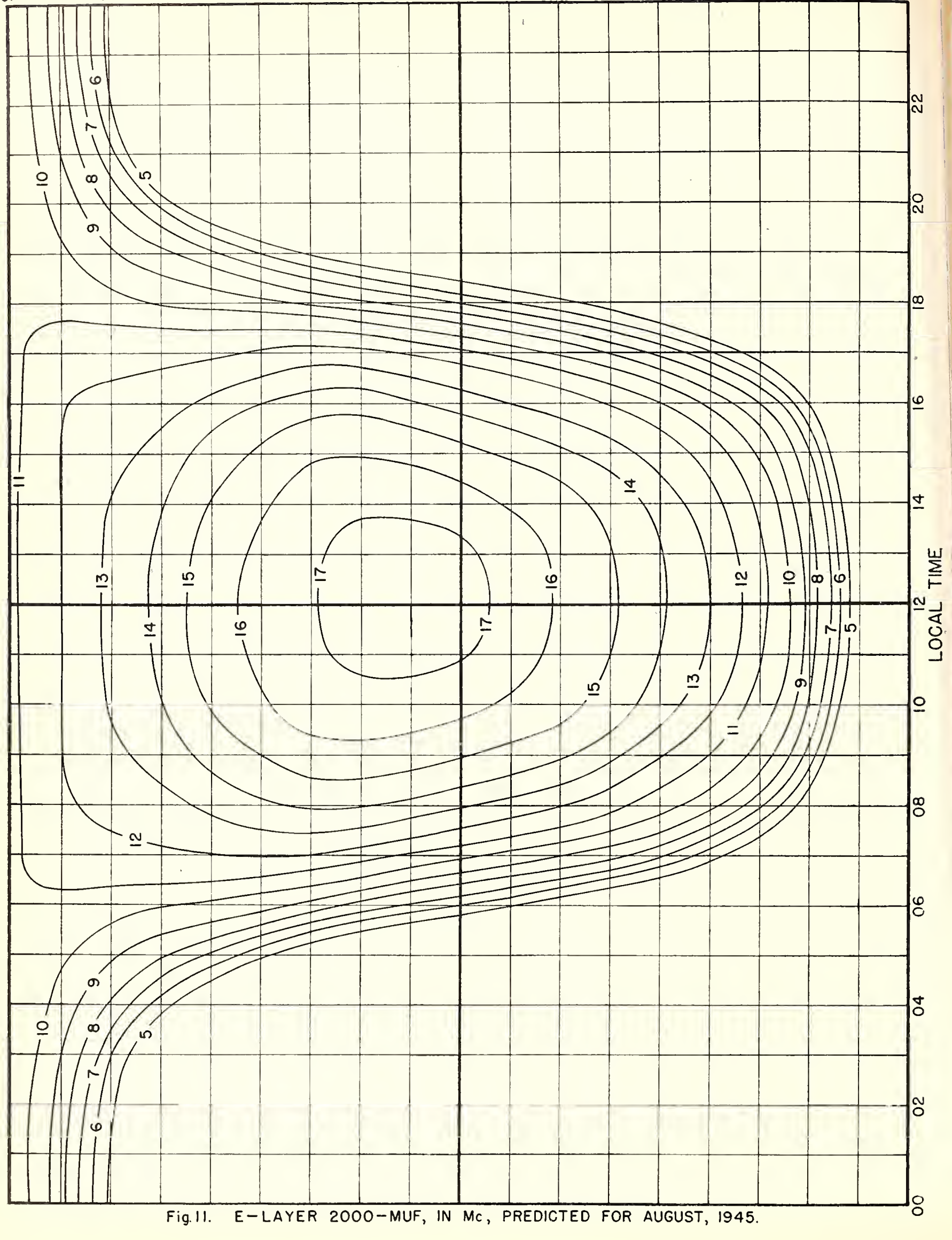
$1 \mathrm{~km}=0.62137$ mile $=0.5396 \mathrm{t}$ nout. $\mathrm{mi}$.

$1 \mathrm{mile}=1.60935 \mathrm{~km}=0.86836$ nout. $\mathrm{mi}$

I nout $\mathrm{mi}=1.85325 \mathrm{~km}=1.1516 \mathrm{mi}$.

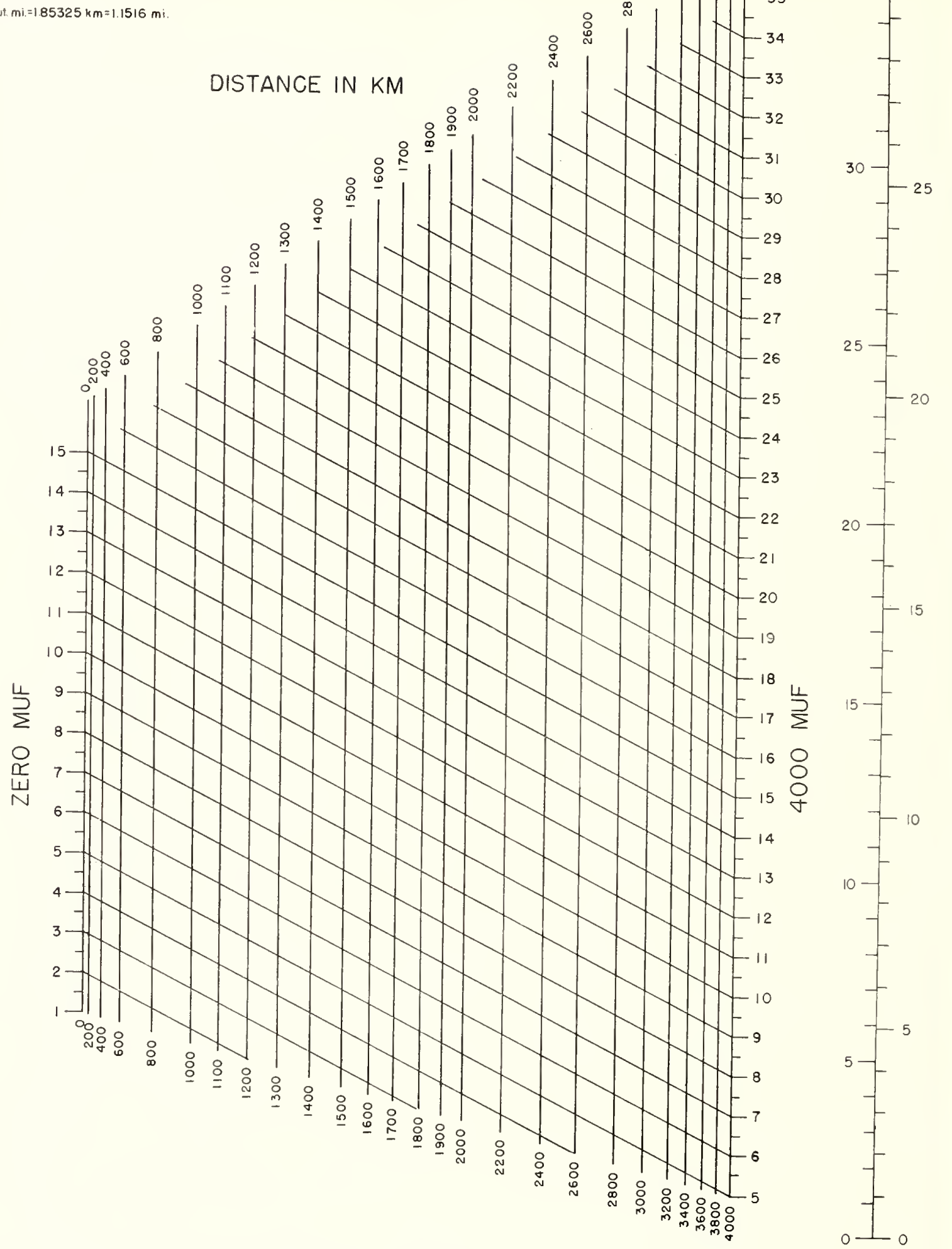

FIG. 13. NOMOGRAM FOR TRANSFORMING $F_{2}$-ZERO-MUF AND $F_{2}-4000-M U F$ TO EQUIVALENT MAXIMUM USABLE FREQUENCIES AT INTERMEDIATE TRANSMISSION DISTANCES; CONVERSION SCALE FOR OBTAINING OPTIMUM WORKING FREQUENCIES. 
2000-Km E muf,

$\mathrm{MC}$
$1 \mathrm{~km}=0.62137$ mile $=0.53961$ nout. $\mathrm{mi}$.

1 mile $=1.60935 \mathrm{~km}=0.86836$ nout $\mathrm{mi}$.

I nout. $\mathrm{mi} .=1.85325 \mathrm{~km}=1.1516 \mathrm{mi}$

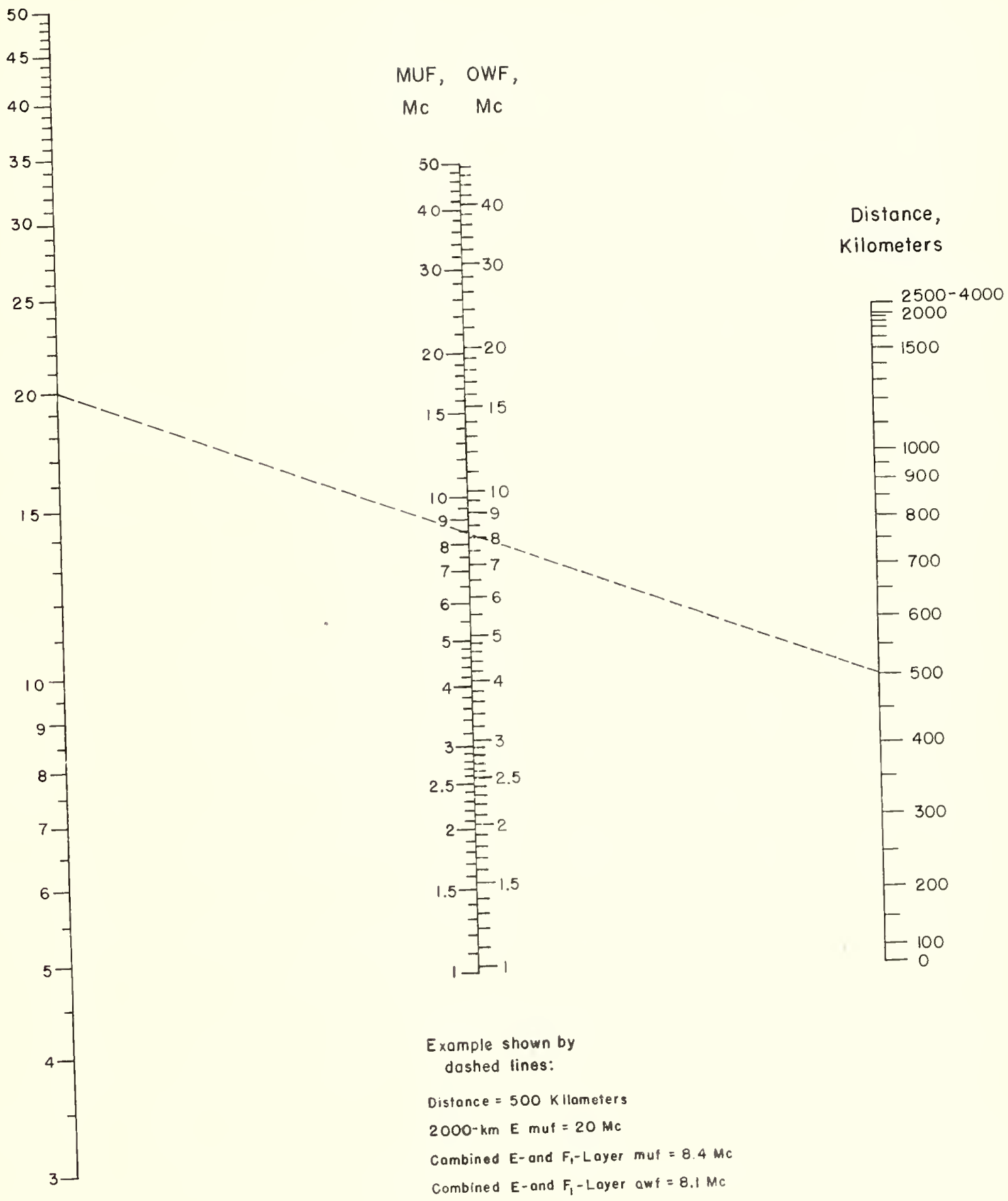

FIG. 14. NOMOGRAM FOR TRANSFORMING E-LAYER 2000-MUF TO EQUIVALENT MAXIMUM USABLE FREQUENCIES AND OPTIMUM WORKING FREQUENCIES DUE TO COMBINED EFFECT OF $E$ LAYER AND F, LAYER AT OTHER TRANSMISSION DISTANCES. 


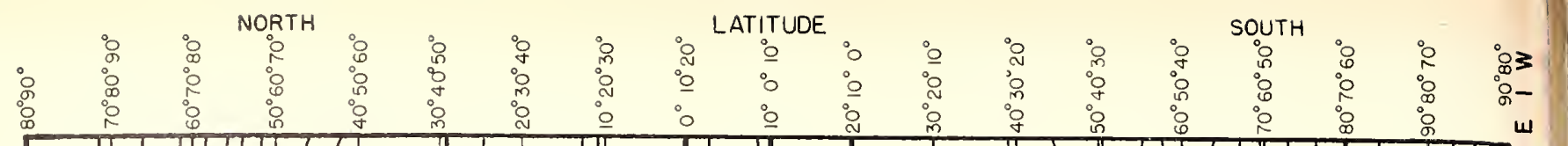
|: $\sqrt[3]{\frac{8}{2}}$

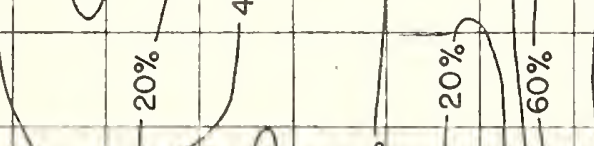

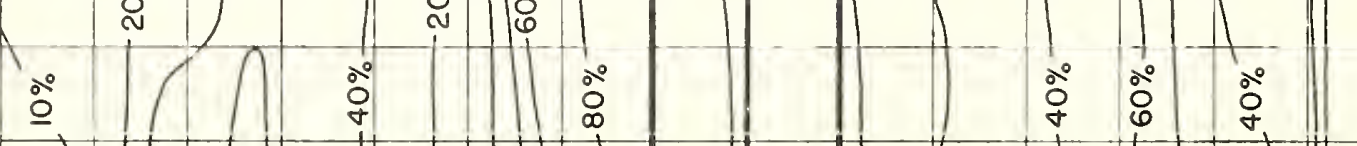

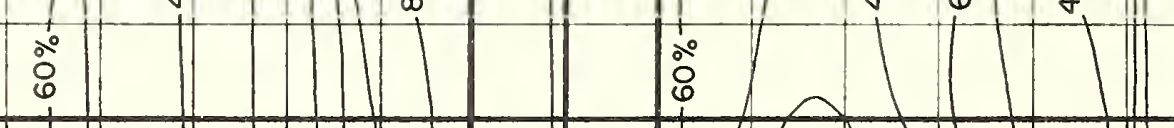

Y|l:

$\stackrel{1}{*}$
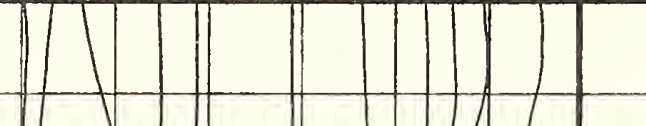

1
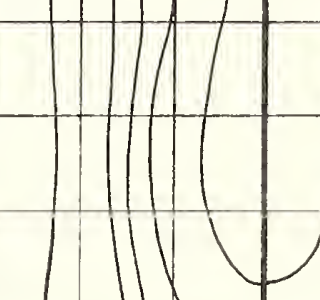

il | III
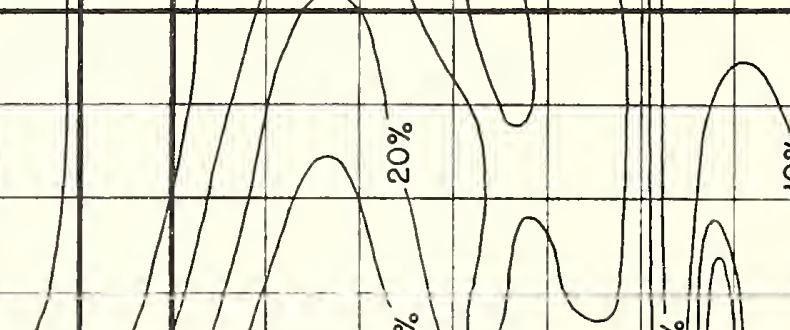

ㅇํㅇ

I
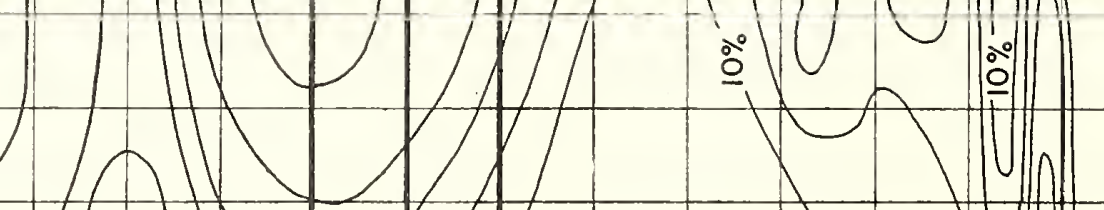

-

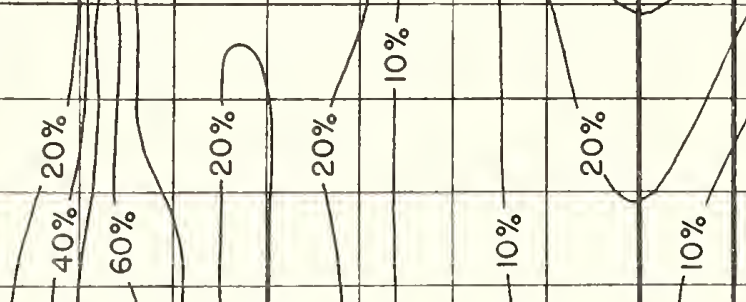

:
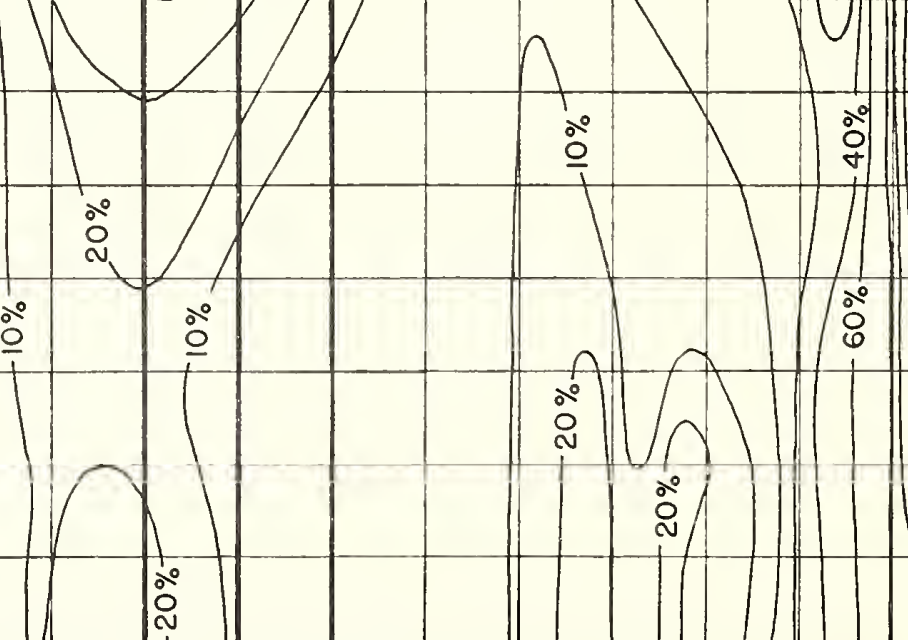

웅

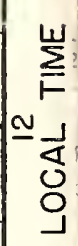

으
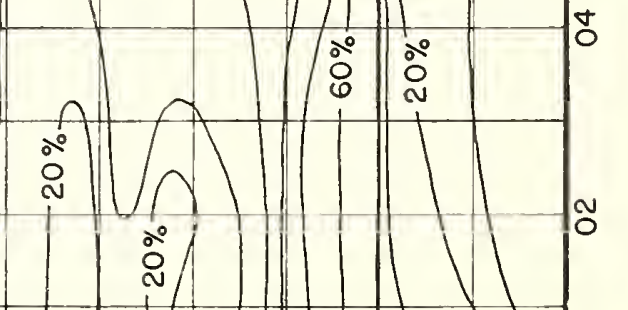

@̊̊

Fig. 15 PERCENTAGE OF TIME OCCURRENCE FOR $E_{S}$ IN EXCESS OF $15 \mathrm{Mc}$, PREDICTED FOR AUGUST, 1945. 


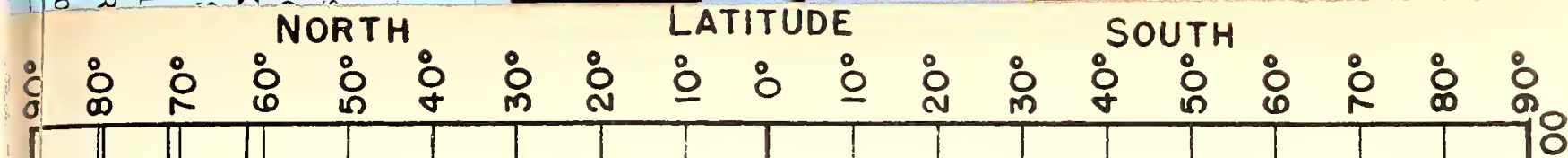

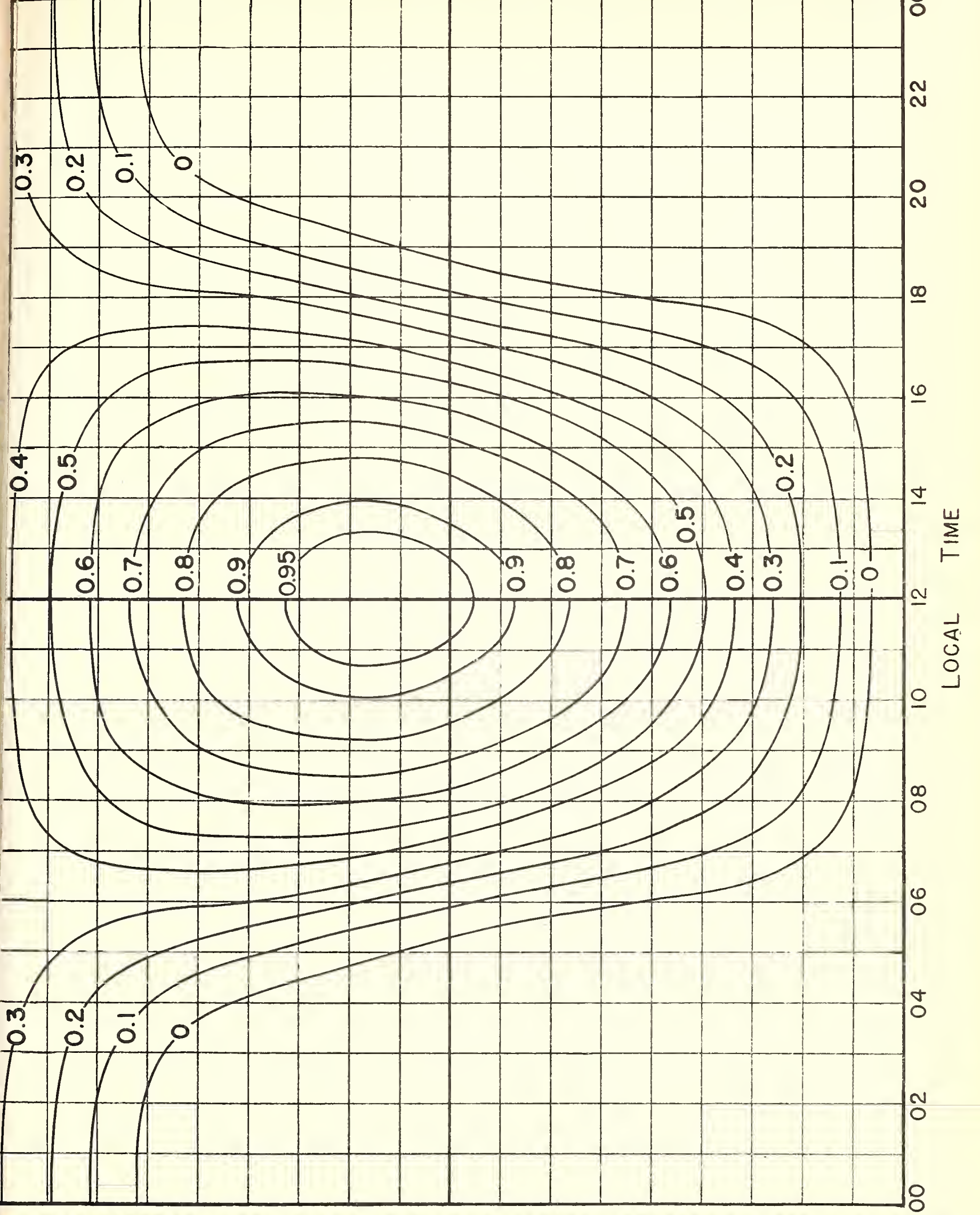

Fig. 16. ABSORPTION INDEX CHART (EXCLUDING AURORAL ABSORPTION) FOR AUGUST. 

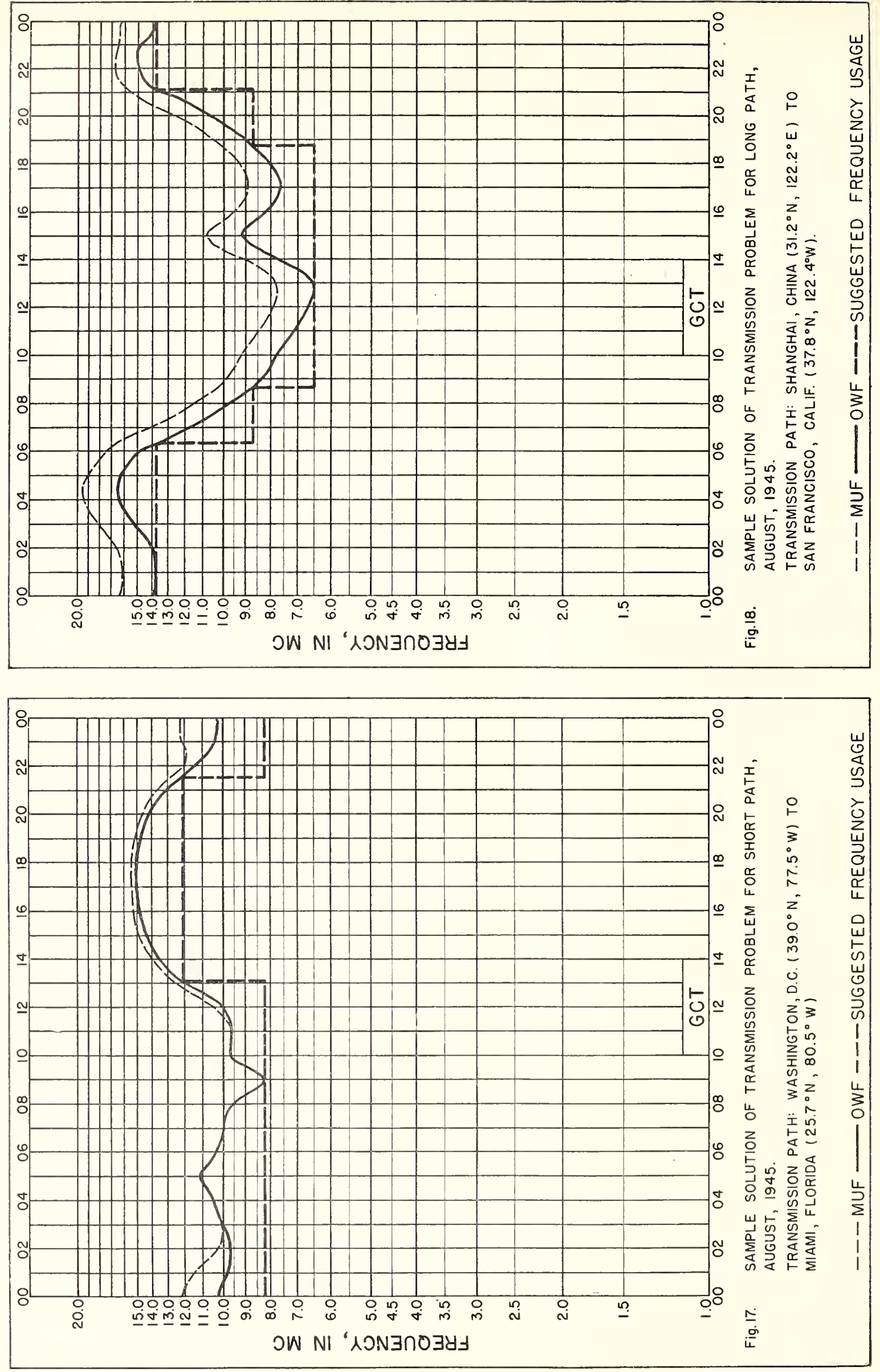


\section{IRPL REPORTS}

Daily:

Telephoned and telegraphed reports of ionospheric, solar, geomagnetic, and radio propagation data from various places.

Radio disturbance warnings.

Semiweekly:

IRPL-J. Radio Propagation Forecast.

Semimonthly:

IRPL-Ja. Semimonthly Frequency Revision Factors for IRPL Basic Radio Propagation Prediction Reports.

Monthly:

IRPL-D. Basie Radio Propagation Predictions-Three months in advance.

IRPL-E. Discontinued.

IRPL-F. Ionospheric Data.

Bimonthly:

IRPL-G. Correlation of D. F. Errors With Ionospheric Conditions.

Quarterly:

IRPL-A. Recommended Frequency Bands for Ships and Aireraft in the Atlantic and Pacific.

IRPL-B. Recommended Frequency Bands for Submarines in the Pacific.

IRPL-K. Best Radio Frequencies for Aircraft and Ground Stations in the Atlantic.

IRPL-M. (WIMS APPENDIX N) Frequency Guide for Merchant Ships.

Semiannual:

IRPL-H. Frequency Guide for Operating Personnel.

Special Reports, etc.:

IRPL Radio Propagation Handbook, Part 1.

IRPL-C1 through C61. Reports and papers of the International Radio Propagation Conference, 17 April to 5 May 1944.

IRPL-R. Unscheduled reports:

R1. Maximum Usable Frequency Graph Paper.

$\mathrm{R} 2$ and R3. Obsolete.

R4. Methods Used by IRPL for the Prediction of Ionosphere Characteristics and Maximum Usable Frequencies.

R5. Criteria for Ionospheric Storminess.

R6. Experimental studies of ionospheric propagation as applied to a navigation system.

R7. Further studies of ionospheric propagation as applicd to a navigation system.

R8. The Prediction of Usable Frequencies Over a Path of Short or Medium Length, Including the Effects of Es. R9. An Automatic Instantaneous Indicator of Ship Distance and MUF.

R10. A method for study of the icnosphere.

IRPL-T. Reports on Troposheric Propagation.

T1. Radar Operation and Weather. (Superseded by JANP 101.)

T2. Radar coverage and weather. (Superseded by JANP 102.) 
